\title{
REKONTRUKSI HUKUM ISLAM ABU AL-A'LA AL-MAUDUDI Upaya Konstruktif Penegakan Hukum Islam di Pakistan
}

\section{Dahlan}

\begin{abstract}
Abstrak: Gerakan pembentukan negara Islam merupakan bagian dari gerakan kebangkitan kembali dan rehabilitasi Islam. Negara-negara yang mayoritas umat Islam berupaya memberi kerangka bagi suatu Konstitusi Islam dan pengenalan hukum Islam. Al-Maududi menggagas empat bentuk upaya konstruktif penegakan hukum Islam di Pakistan. Pertama, upaya pendirian akademi hukum yang mengkaji perbendaharaan hukum Islam. Kedua, menganjurkan kodifikasi hukum Islam berdasarkan al-Qur'an, al-Sunnah, qiyas dan ijma'. Ketiga, mereformasi pendidikan hukum., yaitu melakukan langkah konstruktif dalam aplikasi pendidikan hukum. Keempat, mereformasi sistem peradilan tentang profesi pengacara dan menyelaraskan sistem pengadilan negara dengan standar-standar Islam.
\end{abstract}

Kata-kata kunci: Hukum Islam, rekonstruksi dan gerakan

Abstract: Movement of Islamic state establishment is one of Islamic resuscitative and rehabilitative movement. The Muslim countries attempt to make a frame of an Islamic constitution and Islamic law introduction. Al-Maududi initiated four constructive efforts for empowering Islamic law in Pakistan: Firstly, founding Academy of Law studying the resources of Islamic law; secondly, suggesting codification of Islamic law based on al-Qur'an, alSunnah, qiyas, and ijma; thirdly, reforming education of law with constructive steps in its implementation; and finally, reforming the system of court especially lawyers profession and harmonizing the system of state court with Islamic standards.

Key words: Islamic law, reconstructive and movement 


$$
\begin{aligned}
& \text { الملخص: إن الحركات لوضع الدولة الإسلامية هى من حركات إسلامية للبعث و الإصلاح من } \\
& \text { جديد. و ما زالت الدول المسلمة في محاولة لتحقيق نموذجا للقانون الإسلامى و تعريف شريعته. و قد } \\
& \text { شرع المودودي أربع محاولات لإقامة الشريعة الإسلامية بباكستان كما يلي : الأول، محاولة بياء }
\end{aligned}
$$

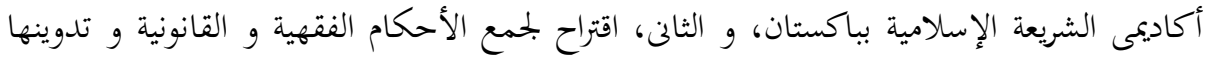

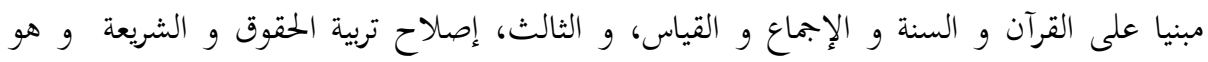

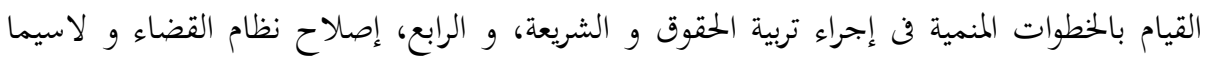

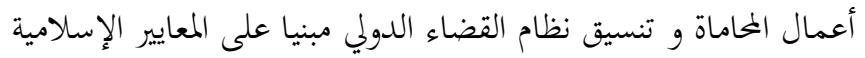

Syari'at Islam diturunkan dalam bentuk yang umum dan garis besar permasalahan. Hukum-hukumnya bersifat tetap, tidak berubah lantaran perubahan masa dan tempat. Syari'at Islam hanya menetapkan kaidah dan memberikan patokan umum untuk hukum-hukum yang lebih rinci. Penjelasan dan rinciannya diserahkan kepada ijtihad para ulama. Syari'at Islam dapat menjadi petunjuk yang universal, dapat diterima di semua tempat dan setiap saat dengan menetapkan ketentuan-ketentuan umum tersebut. Setiap saat umat manusia dapat menyesuaikan tingkah lakunya dengan garis-garis kebijakan al-Qur'an, sehingga tidak melenceng dari ketentuannya. Penetapan al-Qur'an tentang hukum dalam bentuk yang global dan simple itu dimaksudkan untuk memberikan kebebasan pada umat manusia dalam melakukan ijtihad sesuai dengan situasi dan kondisi zaman. Syari'at Islam yang universal diharapkan berlakunya hukum Islam sepanjang masa.

Menurut Juhaya S. Praja, syari'at dalam literatur hukum Islam mempunyai tiga pengertian. Pertama, syari'at dalam arti sumber hukum yang tidak dapat berubah sepanjang masa. Kedua, syari'at dalam pengertian sumber hukum Islam, baik yang tidak berubah sepanjang masa maupun sumber hukum Islam yang 
dapat berubah. Ketiga, syari'at dalam pengertian hukum-hukum yang digali (berdasarkan atas apa yang disebut al-istinbat) dari alQur'an dan al-Sunnah; hukum yang diinterpretasikan dan dilaksanakan oleh para sahabat, ijtihad para mujtahid, dan hukum-hukum yang dihasilkan dengan metode qiyas dan metode hukum lainnya. ${ }^{1}$

Mahmud Syaltut mendefinisikan syari'at berdasarkan pengertian ketiga di atas, yaitu hukum-hukum atau dasar-dasar hukum yang digariskan Allah agar manusia dapat menjadikan pedoman dalam berhubungan dengan Tuhan, sesama umat manusia. $^{2}$ Definisi syari'ah yang dikemukan Mahmud Saltut dapat dibahasakan dalam pengertian al-Maududi bahwa syari'at adalah arahan-arahan bagi pengaturan hidup individu maupun kelompok. Arahan-arahan ini menyentuh aneka ragam subjek seperti berbagai ritual keagamaan, karakter pribadi, moral, adat istiadat, hubungan keluarga, urusan sosial ekonomi, hak pemerintah, dan tugas-tugas warga negara, sistem kehakiman, hukum perang dan damai serta hubungan internasional. Kesimpulannya bahwa syari'at meliputi semua sector kehidupan manusia. Syari'at merupakan rancangan hidup manusia yang lengkap dan tatanan sosial yang seba cukup, dan tidak ada satu pun yang berlebih ataupun berkurang. ${ }^{3}$

Al-Maududi menegaskan bahwa syari'at merupakan keseluruhan organik. Seluruh rancangan kehidupan yang ditetapkan Islam digerakkan oleh semangat yang sama dan pengkotak-kotakan yang sembarangan atas rancangan ini pasti akan merusak baik semangat maupun struktur syari'ah. AlMaududi berkata:

From this discussion, I think, it has became fairly clear that what we, at present, technically call 'Islamic Law' is only a part of a complete scheme of life and does not have any independent existence in isolation from that scheme. It can neither be understood nor enforced separatel. To enforce it 
separately would, in fact, be against the intention of the LawGiver. What is reguered of us is to translate into practice the entire Islamic programme of life and not merely a fragment of it. Then and then alone can the legal aspects be properly implemented. 4

Pernyataan al-Maududi di atas menjelaskan tentang penegakkan hukum Islam ke dalam program kehidupan Islam yang integral. Logika syari'at sebagai suatu sistem perundangundangan agama menunjukkan dengan jelas bahwa syari'at merupakan undang-undang yang dijabarkan langsung dari alQur'an, tradisi atau sunnah Nabi, dan tindakan individu yang terpercaya serta masyarakat yang hidup sesuai dengan wahyu dan tradisi Nabi. Meskipun ijma' dan qiyas tidak disebutkan secara jelas dalam al-Qur'an atau al-Sunnah sebagai sumber syari'at, namun perkembangan kedua konsep itu sebagai sumber syari'at adalah produk dari sumber yang disepakati, yaitu ijtihad para ahli hukum Islam pada abad kedua dan ketiga hijrah. ${ }^{5}$

Pada periode selanjutnya, Ibn Taimiyah dicatat sebagai perintis terpenting pembaharuan hukum Islam. Ditempatkan sebagai orang pertama dan terakhir yang menentang kekakuan dan kesia-siaan taqlid, mengikuti secara buta pemimpinpemimpin mazhab fiqh. Masalah yang relavan di sini adalah tujuan-tujuan atau metodologi pembaharuan Ibn Taimiyah sebagai penyeru revivalisme Islam dan pembaru (mujadid) yang sering dianggap para pendukung syari'at sebagai suatu model bagi upaya menyegarkan kembali Islam. Daya tarik utama Ibn Taimiyah bagi para pendukungnya adalah obsesinya menentang tatanan yang mapan dan menegaskan kembali hak untuk melakukan ijtihad, meskipun keyakinan umum berpendapat bahwa pintu ijtihad telah tertutup sejak abad X M. Ibn Taimiyah menyakini telah menjalankan tugas memperbaharui syari'at dan mempertahankan nilai-nilai agama. Aspek lain dari perannya sebagai model kebangkitan Islam adalah tuntutannya yang tidak 79 Al-Fikra: Jurnal Ilmiah Keislaman, Vol.3, No.1, Januari-Juni 2004 
kenal kompromi terhadap penerapan total syari'at, baik dalam kehidupan publik maupun pribadi. ${ }^{6}$

Ibn Taimiyah menawarkan kepada para pendukung syari'at modern suatu model untuk menantang kekakuan mazhab fiqh yang mapan, yaitu suatu kombinasi antara komitmen terhadap penerapan syari'at secara kaku dengan pandangan dasar negara Islam yang secara terminologis tidak berbeda dengan kontrak sosialnya teori politik modern. Penekanannya pada kewajiban imam untuk mentaati hukum dan berkonsultasi dengan warga negaranya, bisa jadi dalam istilah modern dikenal sebagai komitmen pada aturan hukum (rule of law) dan pemerintahan demokratis. ${ }^{7}$

Literatur tentang penerapan syari'at modern terlalu luas untuk ditinjau secara rinci. Karena itu vitalitas wacana penerapan syari'at di Pakistan, cukup mewakili perdebatan yang sedang berlangsung di negara-negara lainnya di dunia Islam. Pemikiran bangsa Pakistan tentang hal yang sama dapat ditelaah kembali melalui survei luas yang dilakukan oleh Ishtiaq Ahmed yang mengatakan bahwa para pendukung syari'at di Pakistan adalah kaum absolutis, ${ }^{8}$ al-Maududi, Asad, Perwes, Hakim dan Javid Iqbal. ${ }^{9}$

Para pendukung negara syari'at bangsa Pakistan punya komitmen pada al-Qur'an dan al-Sunnah sebagai sumber hukum yang menjiwai namun berbeda dengan memegangi fiqh (yurisprudensi) Islam. Sedangkan kaum absolutis dan al-Maududi melihat keseluruhan syari' at dan yurisprudensi dapat diterapkan secara langsung dalam kehidupan. ${ }^{10}$

Al-Maududi mengatakan bahwa rancangan syari'at dibagi menjadi beberapa bagian. Pertama, ada bagian yang tidak membutuhkan kekuatan luar manapun untuk menegakkannya. Bagian ini telah dan dapat ditegakkan hanya dengan kesadaran yang terus menyala yang diterangi iman dalam diri seorang muslim. Kedua, ada bagian yang hanya dapat ditegakkan dengan program pendidikan Islam, menatar karakter manusia dan 80 Al-Fikra: Jurnal Ilmiah Keislaman, Vol.3, No.1, Januari-Juni 2004 
menyucikan hati serta moralnya. Ketiga, ada bagian yang harus ditegakkan dengan menggunakan pendapat umum, yaitu kehendak umum dan tekanan masyarakat. Keempat, ada bagian yang telah disahkan oleh tradisi dan konvensi masyarakat Islam. Sebagian besar hukum Islam memerlukan penegakan kekuasaan untuk memaksa dan wewenang negara dengan semua rinciannya. Kekuatan politik merupakan hal yang paling penting untuk melindungi sistem kehidupan Islam dari kemerosotan dan kemusnahan; untuk membasmi kejahatan dan menegakkan kebenaran; dan untuk menegakkan semua hukum yang memerlukan sanksi-sanksi negara dan pengadilan dalam penyelenggaraannya. ${ }^{11}$

Al-Maududi menyimpulkan bahwa dari sudut yuridis, bagian yang terakhir inilah yang cocok bagi penerapan istilah hukum Islam. Karena perintah dan peraturan ini sajalah yang ditunjang oleh kewenangan politis yang di dalam pengertian modern diberi istilah "hukum". Tetapi sepanjang berkaitan dengan konsepsi Islam, keseluruhan syari'at berperan sebagai sinonim dari "Hukum", karena seluruh norma hidup telah difirmankan Allah swt. Namun, untuk mencegah kebingungan, penerapan istilah hukum Islam hanya untuk syari'at-syari'at yang memerlukan sanksi kekuasaan negara dalam penegakannya. ${ }^{12}$

Gerakan untuk memperkenalkan hukum Islam dan pembentukan negara Islam adalah bagian dari gerakan kebangkitan kembali dan rehabilitasi Islam. Negara-negara yang mayoritas umat Islam berupaya keras untuk memberi kerangka bagi suatu Konstitusi Islam dan pengenalan hukum Islam. Pakistan, Sudan, Somalia, Malasyia, Indonesia, dan seterusnya menjadi saksi atas gerakan yang sama.

Pemikiran tentang penegakan hukum Islam dalam negara Islam memfokuskan permasalahan tentang bagaimana upaya konstruktif al-Maududi dalam penegakan hukum Islam di Pakistan? Pokok permasalahan dibatasi dalam persoalan tentang upaya konstruktif penegakan hukum Islam yang membahas 81 Al-Fikra: Jurnal Ilmiah Keislaman, Vol.3, No.1, Januari-Juni 2004 
seputar akademi hukum, kodifikasi hukum, reformasi hukum dan reformasi pendidikan hukum dan reformasi sistem peradilan.

\section{Akademi Hukum}

Di kalangan umat Islam, Maududi bukanlah sosok (figur) yang asing, bukan pula seorang spesialis yang hanya menekuni satu bidang kajian ilmu pengetahuan, tetapi ketenarannya mampu menyamai para ulama dan intelektual yang ada di masanya. Maududi banyak melahirkan karya dalam pemikiran seperti bidang disiplin ilmu tafsir, hadis, teologi, filsafat, sejarah, politik, ekonomi, sosial budaya dan juga pemikiran hukum. ${ }^{13}$

Dalam kerangka pemikirannya tentang hukum cenderung menyepakati adanya upaya pendirian Akademi Hukum yang berusaha mengkaji perbendaharaan hukum yang telah diwariskan oleh para pendahulu (nenek moyang). Akademi Hukum yang dimaksudkan bukan semata-mata penterjemahan kitab, akan tetapi mengadakan suatu forum kajian lebih lanjut dalam menginterpretasikan kandungan perundang-undangan yang dapat ditinjau kembali pemahamannya melalui berbagai dimensi, baik dimensi yang dikaitkan dengan fenomena modern, dimensi penyuntingan kembali makna sebuah pasal atau ayat, ataupun dimensi yurisprudensi yang disesuaikan dengan kebutuhan tuntutan kemanusiaan. ${ }^{14}$

Penyuntingan kembali hukum-hukum tersebut dapat dilakukan oleh para cendekiawan dengan cara mengoleksi kembali perbendaharaan karya-karya yang telah diwariskan nenek moyang dan menyuntingnya ke dalam bentuk Kitab Hukum Modern, yang telah diperbaharui dalam format yang fleksibel (dapat diinterpretasikan sesuai keberadaan dan perkembangan dunia).

Dalam pandangan al-Maududi menginginkan buku-buku perundang-undangan yang diterjemahkan ke dalam bahasa

82 Al-Fikra: Jurnal Ilmiah Keislaman, Vol.3, No.1, Januari-Juni 2004 
Nasional Pakistan, diambil dari kitab-kitab yang bersumber dari bahasa Arab. ${ }^{15}$ Keinginannya disebabkan kondisi sosio-historis tuntutan masyarakat di masanya penuh dengan degradasi moral yang mengakibatkan terlecehkannya ajaran Islam yang notabene adalah al-Qur'an dan al-sunnah; atau keinginan untuk menerapkan hukum Islam secara murni, sehingga buku-buku rujukan yang dikoleksi, dikutip dari berbagai literatur Arab atau dilatarbelakangi oleh bahasa Arab itu sendiri yang merupakan bahasa resmi agama Islam dalam beribadah kepada Allah swt.

Mengetahui tentang kondisi sosio-historis masyarakat di masa Abul A'la al-Maududi, dapat dilihat beberapa tahun sebelumnya, ketika Muhamad Iqbal ${ }^{16}$ dengan lantang menyeruakan suaranya melalui gagasan-gagasan syariat Islam. Iqbal menyatakan bahwa Islam yang berkembang di masanya telah diracuni oleh ajaran-ajaran panteisme yang menafikan keberadaan pribadi dan memandangnya hanya sebagai sebuah bayangan yang menyesatkan. Ini menimbulkan pengaruh yang tidak sehat bagi perkembangan Islam, karena pandangan ini telah meruntuhkan nilai-nilai spritual, budaya dan politik umat Islam di berbagai negara selama berabad-abad. Menurut Iqbal, pengaruh negatif yang ditimbulkan oleh panteisme adalah fatalisme. Manusia tidak mempunyai kemampuan untuk melakukan sesuatu, karena dalam pandangan ajaran tersebut, alam dunia ini hanya bayangan (maya) yang semu. ${ }^{17}$

Beberapa komentar Maududi tentang pengumpulan karyakarya para pendahulu, sama sekali tidak mengomentari adanya suatu indikasi untuk mengadopsi sistem hukum dari dunia Barat dan Eropa (seperti Belanda yang terkenal dengan produk hukumnya yang brilian), padahal dalam rangka melegitimasi sebuah perundang-undangan hukum menuju tuntutan modern sekarang, ada baiknya membandingkan produk hukum luar negeri (Eropa-Barat) dan merelevansikannya dengan produk hukum Pakistan dan sumber-sumber hukum yang diambil dari kitab-kitab berbahasa Arab.

83 Al-Fikra: Jurnal Ilmiah Keislaman, Vol.3, No.1, Januari-Juni 2004 
Memang, Maududi mempelajari produk-produk hukum luar negeri, tetapi hanya sebatas pengetahuan dan bukan untuk diaplikasikan ke dalam perundang-undangan di Pakistan. Pandangannya yang demikian, merupakan imbas dari penjajahan Inggris yang mengatur pemerintahan Pakistan (dulunya India) dengan berbagai keinginan mereka sendiri tanpa memperhatikan kepentingan umat Islam yang mayoritas di Pakistan.

Dalam rangka melegitimasi ide tentang akademi hukum, Maududi mengukuhkan pendapat tentang pentingnya menterjemahkan 3 buah buku Ahkam al-Qur'an (perintah hukum al-Qur'an) yang berkaitan dengan perintah-perintah hukum yang mengandung semua rincian yang relevan dengan hadis dan perkataan serta praktek para sahabat dalam kehidupan sehari-hari mereka. Ketiga buku tersebut adalah al-Jasas, Ibn al-'Arabi dan Qurtubi. ${ }^{18}$ Pemikiran dan kekentalan ajaran Islam dalam sanubari Maududi semakin terlihat ketika meluncurkan buku yang dirintisnya selama 30 tahun, yaitu buku Tafhim al-Qur'an..$^{19}$ Ciri utama buku ini adalah dalam menyampaikan arti dan pesan dalam bahasa dan gaya yang menyentuh hati dan pikiran orang, serta menunjukkan relevansi al-Qur'an dengan masalah-masalah yang mereka hadapi setiap hari, baik sebagai individu maupun dalam masyarakat. ${ }^{20}$

Sejauh yang dapat dipantau, al-Maududi pada hakikatnya mendambakan produk hukum yang bersumber dari Tuhan, dijalankan menuju Tuhan dan akan dipertanggungjawabkan di hadapan Khaliq. Ini berarti menunjukkan tingginya hasrat dan cita-cita ideal Maududi untuk memposisikan manusia dalam lingkaran serta batas-batas pemantauan Allah swt. Hal ini sejalan dengan konsep teokrasi (Kingdom of God) yang dicetuskannya, di mana Allah adalah pemegang kekuasaan tertinggi (Pembuat syariat). ${ }^{21}$ Mencermati pola dan konsep teokrasi ini, berarti para hakim atau pemimpin yang memutuskan hukum bagi seseorang akan mempertanggungjawabkannya di hadapan Tuhan, bukan saja di hadapan manusia ketika terjadi persidangan. Persidangan 84 Al-Fikra: Jurnal Ilmiah Keislaman, Vol.3, No.1, Januari-Juni 2004 
harus memutuskan suatu perkara semurni mungkin tanpa adanya gangguan dari pihak-pihak luar.

Pemikiran Maududi di atas berdasarkan al-Qur'an, ${ }^{22}$ di antaranya Q.S. al-Zumar: 2-3:

$$
\text { انا انزلنا اليك الكتاب بالحق فاعبد الله مخلصاله الدين. الا لله الدين الخالص.... }
$$

Artinya: Sesungguhnya Kami menurunkan kepadamu kitab alQur'an dengan membawa kebenaran. Maka sembahlah Allah dengan memurnikan ketaatan kepada-Nya. Ingatlah, hanya kepunyaan Allahlah agama yang bersih...(Q.S. 39: 2)

Dalam Q.S. al-Zumar 11, dijelaskan: “Sesungguhnya aku diperintahkan supaya menyembah Allah dengan memurnikan ketaatan kepada-Nya dalam menjalankan agama. Dan aku diperintahkan supaya menjadi orang yang pertama-tama berserah diri". Al-Maududi sangat berhati-hati untuk menerapkan perundang-undangan hukum di Pakistan, terutama hal-hal yang berhubungan erat dengan kehidupan dan budaya nasional negara. Maududi hanya mereformasi sebatas cara dan alat yang diperlukan untuk mendalami pemahaman yurisprudensi dan hukum Islam ke dalam bahasa nasional negara Pakistan. ${ }^{23}$ Cara dan alat tersebut diharapkan dapat menjembatani pemahaman masyarakat tentang sebuah hukum. Perlu perencanaan yang matang dalam menerapkan dan mengaplikasikan pemahaman yurisprudensi yang masih kabur dalam pemikiran mayoritas masyarakat Pakistan.

Melihat urgensitas pemahaman ini, pada hakikatnya Maududi menghendaki dibentuknya suatu pendidikan hukum sedini mungkin, mulai dari jenjang pemula sampai kepada jenjang yang paling tinggi. Semua stratifikasi (jenjang) pendidkan hukum 
tersebut saling terkait dan saling mendukung. Para orang tua diharapkan mampu memberikan pendidikan hukum kepada anak mereka sebagai usaha untuk mematangkan pemahaman anak dalam dunia kehidupan yang dijalani. ${ }^{24}$

Dalam usaha tersosialisasinya pemahaman hukum yang mantap bagi segenap masyarakat, Maududi memandang perlu mendirikan beberapa lembaga hukum, baik yang berbentuk sekolah dan perguruan tinggi serta pendirian kursus-kursus hukum yang diarahkan kepada pematangan hukum yang kelak menghasilkan produk-produk yang mahir, cakap, handal dan mampu memahami (memberi solusi terbaik) dalam segala macam bentuk permasalahan yang dihadapi manusia. ${ }^{25}$ Bahkan dalam pandangan Maududi, anak-anak di usia sekolah dasar dikenalkan tentang pemikiran-pemikiran hukum dasar yang diharapkan kelak menjadi benteng penyangga bagi mereka untuk mengetahui hukum lebih mendalam di jenjang pendidikan selanjutnya. Para orang tua dalam hal ini harus menjalin hubungan kerja sama dengan pihak sekolah atau akademi berupa link and match, dalam arti orang tua mengawasi seluruh gerak gerik anak dari belakang, dan berusaha mengarahkan pemikiran hukum yang telah diperoleh anak di sekolah atau di akademi hukum. Jadi, orang tua juga harus paham permasalahan hukum yang merupakan bagian dari kegiatan dan aktivitas manusia di dunia. ${ }^{26}$

Lembaga-lembaga hukum, kursus-kursus hukum serta sekolah-sekolah yang sengaja diformat sebagai tempat dikadernya para penegak hukum, diharapkan melahirkan ide-ide jenius dan brilian yang kelak mencetuskan hukum-hukum tertulis yang menjadi rujukan hukum di negara Pakistan, yaitu hukum-hukum yang memiliki berbagai ide dan wawasan universal sesuai dengan sumber-sumber hukum yang paling asasi sebagaimana diharapkan Maududi. ${ }^{27}$

Para ahli hukum (lawyer) yang lahir dari hasil produk lembaga-lembaga, akademi dan kursus-kursus hukum tadi, diharapkan mampu melahirkan berbagai keputusan serta dekrit- 
dekrit yang mengorbitkan sebuah perundang-undangan hukum tertulis, baik hukum perdata, pidana, serta masalah-masalah konstitusi dan hukum internasional, yang gambarannya disesuaikan dengan tuntutan masyarakat modern. Dengan lahirnya konsep-konsep hukum ini, diharapkan pula penegakan hukum di Pakistan benar-benar tercermin sesuai dengan harapan dan keinginan semua lapisan masyarakat serta mengikuti draftdraft pasal secara murni dan konsekuen, sehingga nantinya penduduk merasa tenang dan damai dalam kepastian hukum.

Bila dikaitkan dengan hukum-hukum tertulis di negara Indonesia, dalam pandangan Yusril Ihza Mahendra, ternyata hukum-hukum yang dijadikan rujukan bagi pedoman hukum di Indonesia termasuk falsafah negara (Pancasila), Undang-Undang Dasar 1945, GBHN, Kepres, dan perundang-undangan yang mencakup semua tindak pidana, perdata dan kriminal lainnya. Rujukan hukum-hukum ini diambil dari fenomena pluralitas kebudayaan dan keanekaragaman yang ada di nusantara. Hukum-hukum ini meliputi seluruh agama yang ada di Indonesia, oleh sebab itu sila pertama dari Pancasila adalah Ketuhanan Yang Maha Esa, yang mengindikasikan atau mewajibkan penduduk yang berdomisili di Indonesia memiliki agama. Orang-orang yang tidak memiliki agama tidak boleh tinggal di Indonesia, karena dipandang sebagai pembangkang yang tidak mengindahkan peraturan dan kebijakan yang diambil negara. ${ }^{28}$

Sejalan dengan itu, bila dirujuk kembali kepada produk perundang-undangan Pakistan yang diutarakan Maududi, falsafah negara Pakistan tidak dikaitkan dengan produk hukum yang diformat melalui undang-undang tertulis. Akan tetapi produk hukum itu didasarkan kepada pengaruh berbagai pandangan modern yang sesuai dengan tuntutan dan keinginan masyarakat, dalam batas-batas ketentuan Allah swt. (merujuk kepada al-Qur'an dan al-sunnah). ${ }^{29}$ Mencermati pandangan pertanggungjawaban hukum yang demikian, dapat disimpulkan 87 Al-Fikra: Jurnal Ilmiah Keislaman, Vol.3, No.1, Januari-Juni 2004 
bahwa Maududi mendeklarasikan semua kegiatan hukum yang akan diputuskan di antara manusia akan dipertanggungjawabkan sepenuhnya kepada Allah swt, karena Allah merupakan pengambil kebijaksanaan yang Maha Tinggi. Para hakim hanya sebatas perpanjangan tangan Tuhan di muka bumi.

Melihat formulasi pertanggungjawaban hukum alMaududi, ${ }^{30}$ dalam pengamatan Yusril Ihza Mahendra, formulasi ini persis sama dengan konsep formulasi pertanggungjawaban hukum yang ditawarkan oleh Masyumi pada dekade tahun 1945, yang memuat hampir seluruh teks Universal Declaration of Human Rights dari PBB, di mana "kedaulatan rakyat" harus dilakukan dengan berpedoman kepada norma-norma syari'ah dan tidak melampaui "batas" yang telah ditetapkan oleh Tuhan. ${ }^{31}$ Ini menunjukkan bahwa tokoh-tokoh Masyumi berusaha untuk mensintesiskan dua paham kedaulatan yang dikenal dalam falsafah politik modern, yaitu paham kedaulatan Tuhan dan kedaulatan rakyat, yang seringkali dianggap sebagai dua konsep yang bertentangan.

Meskipun draft naskah undang-undang dasar yang dirumuskan Masyumi secara tegas menyatakan bahwa "kedaulatan adalah di tangan rakyat". Penafsiran seperti ini diperkuat lagi dengan bagian klausul yang menyebutkan bahwa kedaulatan rakyat adalah amanah Tuhan kepada mereka. ${ }^{32}$ Penyimpangan yang dilakukan terhadap kedaulatan rakyat, berarti penyimpangan terhadap amanah Tuhan. Melanggar amanah Tuhan berarti dosa, dan ganjarannya akan diterima di hari Pembalasan-Nya.

Paradigma kondisi penegakan hukum seperti di atas, bila berjalan secara baik, serasi dan seimbang, maka penegakan hukum berjalan baik dan dapat memuaskan semua pihak. Sebaliknya bila penegakan hukum hanya sebatas kepentingan orang-orang tertentu, maka hukum sampai kapan pun tidak akan pernah menyelesaikan masalah orang-orang tertindas. 


\section{Kodifikasi Hukum}

Dalam upaya konstruktif penegakan hukum di Pakistan, Maududi menginginkan adanya lembaga cendekiawan Islam dan para ahli pemikiran hukum modern yang dapat melakukan kodifikasi hukum Islam dalam bab demi bab, pasal demi pasal dan ayat demi ayat. ${ }^{33}$ Al-Maududi menganjurkan kodifikasi hukum Islam diambil berdasarkan empat sumber yaitu:

1. Perintah yang jelas dari al-Qur'an

2. Perintah yang jelas atau larangan dari Rasulullah saw. (hadis)

3. Penafsiran, inferensi, qiyas (analogi), ijtihad (istihsan) yang telah mencapai ijma' di kalangan umat atau merupakan keputusan mayoritas ulama yang telah diakui

4. Ijma' atau keputusan mayoritas mengenai persoalan penafsiran, inferensi, qiyas dan dalil hukum lainnya. ${ }^{34}$

Keempat sumber ini merupakan rujukan paling asasi dalam persepsi Maududi. Al-Maududi menegaskan bahwa kemunculan mazhab-mazhab fiqh, firqah-firqah keislaman dan jama'ah (kelompok) yang menamakan dirinya sebagai aliran murni keislaman boleh saja mengklaim dirinya sebagai sumber atau rujukan untuk meminta perkataan atau pendapatnya tentang suatu masalah hukum yang ada, tetapi tidak ada kewajiban untuk menerima setiap perkataan dan pendapat seorang tokoh ilmu fiqh atau para pemimpin dalam sebuah firqah. Hal ini disebabkan semua yang tercantum dalam suatu kitab fiqh atau pedoman sebuah firqah dalam memutuskan suatu perkara tidaklah membentuk suatu hukum Islam.

Dalam konsep Maududi, selain al-Qur'an dan hadis sebagai rujukan mutlak suatu hukum, penggunaan qiyas (analogi), ijtihad (istihsan) juga mendapat perhatian khusus. Ini disebabkan segala permasalahan kehidupan yang melanda umat manusia belum tersahuti oleh dalil-dalil ahkam yang ada dalam al-Qur'an. Pemikiran Maududi yang menjadikan qiyas dan ijtihad sebagai 
salah satu rujukan hukum yang pantas diandalkan, bisa dimaklumi karena ayat-ayat al-Qur'an itu sendiri bukanlah jaminan kepastian dalam menetapkan suatu keputusan akan tetapi al-Qur'an adalah contoh hukum yang dibebankan kepada umat manusia, yang tidak memuat persoalan-persoalan dunia secara rinci. Al-Qur'an hanya memuat garis besar permasalahan dan memberikan prinsip-prinsip dasar yang universal, sehingga tetap relevan dengan perkembangan masyarakat sepanjang zaman. Nabi Muhammad lah satu-satunya yang menjadi interpretator (pemberi interpretasi, inferensi, penafsiran) alQur'an lebih dalam. Semasa hidupnya, beliaulah yang menjabarkan makna-makna global al-Qur'an ke dalam bentuk teknis operasional, baik dalam bentuk perkataan, perbuatan ataupun ketetapan. Inilah yang kemudian disebut dengan hadis dan menjadi sumber kedua dari hukum Islam.

Muhammad Iqbal sependapat dengan arah pemahaman di atas, ia mengomentari bahwa sesungguhnya al-Qur'an tidaklah memberikan banyak prinsip-prinsip umum; untuk sebagian besar ia memberikan solusi dan keputusan terhadap masalah-masalah historis yang spesifik dan konkret; tetapi al-Qur'an memberikan, baik secara eksplisit atau implisit, alasan-alasan di balik solusisolusi dan keputusan-keputusan tersebut dari mana dapat disimpulkan prinsip-prinsip umum. ${ }^{35}$ Inilah, satu-satunya cara meyakinkan untuk menarik kebenaran yang sesungguhnya mengenai ajaran al-Qur'an.

Kedua sumber hukum (al-Qur'an dan hadis) tidak mungkin bertambah lagi setelah wahyu al-Qur'an sempurna turunnya dan Nabi Muhammad saw. wafat. Karena hal ini berarti bahwa hukum Islam sudah sempurna pula untuk mengatur kepentingan manusia. Akan tetapi, sejalan dengan gerak kemajuan masyarakat, timbul satu persoalan; di satu sisi al-Qur'an dan hadis sebagai sumber hukum Islam sudah cukup dan tidak mungkin turun lagi. Tapi di sisi lain masyarakat semakin kompleks. Di sini, pertanyaan yang relevan untuk diajukan 90 Al-Fikra: Jurnal Ilmiah Keislaman, Vol.3, No.1, Januari-Juni 2004 
adalah, bisakah sumber hukum Islam, al-Qur'an dan hadis Nabi yang terbatas itu (dalam arti kuantitatif) mengantisipasi masalah yang semakin kompleks? Menjawab persoalan dengan melakukan ijtihad menggali kedua sumber hukum Islam tersebut secara kreatif.

Menurut Maududi, ijtihad adalah upaya maksimal untuk seseorang untuk meyakini perintah Islam serta maksud yang sesungguhnya dari perintah Islam yang menyangkut masalah atau urusan tertentu, baik mengenai kasus-kasus yang telah diterangkan nashnya maupun tidak. Ijtihad itu tidak pernah mandiri, yang sama sekali terlepas dari syari'ah. ${ }^{36}$

Abdul Hamid Hakim mendefenisikan ijtihad sebagai kemampuan untuk memperoleh hukum syara' dengan cara istinbath terhadap kitab Allah dan sunnah Rasul-Nya. ${ }^{37}$ Ibn Subki merumuskan ijtihad sebagai pengerahan segenap daya upaya dan kemampuan oleh seorang ahli fiqh untuk memperoleh pengetahuan tentang hukum (syara') yang bersifat zhanni. ${ }^{38}$

Iqbal dalam The Reconstruction of Religious Thought in Islam merumuskan ijtihad sebagai "exert with a view to form an independent judgement on legal question"39 (bersungguh-sungguh dalam membentuk suatu keputusan yang bebas untuk menjawab permasalahan hukum). Ijtihad ini kata Iqbal, berasal dari Q.S. alAnkabut: 69: "Dan orang-orang yang berjihad untuk mencari keridhaan Kami, benar-benar akan Kami tunjukkan kepada mereka jalanjalan Kami...".

Ijtihad inilah yang selama berabad-abad dikembangkan dan dimodifikasi oleh para ahli hukum Islam dalam mengantisipasi setiap permasalahan masyarakat yang muncul, sehingga melahirkan aneka ragam pendapat (madzhab). Bagi Iqbal, satu-satunya upaya untuk membuang kekakuan hukum Islam yang dihasilkan pada periode kemunduran Islam adalah menggalakkan kembali ijtihad ijma' dan merumuskannya sesuai dengan kebutuhan zaman modern saat sekarang. Namun demikian, rumusan ijtihad juga harus tetap mengacu kepada 91 Al-Fikra: Jurnal Ilmiah Keislaman, Vol.3, No.1, Januari-Juni 2004 
kepentingan masyarakat dan kemajuan umum. Bukan berdasarkan pemikiran-pemikiran spekulatif subjektif yang bertentangan dengan semangat dan nilai dasar hukum Islam. ${ }^{40}$

Seirama dengan langkah kebijakan yang diambil oleh Iqbal, Maududi memberikan persyaratan pokok bagi tercapainya suatu ijtihad yang sehat. Persyaratan itu adalah:

1. Iman terhadap syari'ah dan yakin atas kebenarannya; niat tulus untuk mengikutinya; tidak berniat untuk bertindak sembarangan terhadapnya; dan bersedia menggali inspirasi serta menyerap semua sasaran, prinsip dan nilai-nilainya, bukan menyerap dari sumber-sumber lain

2. Memahami dengan benar bahasa Arab, tata bahasa dan literaturnya, karena al-Qur'an diturunkan dengan bahasa Arab dan sarana untuk meyakini al-sunnah juga tergantung padanya

3. Pengetahuan serta wawasan dalam ajaran-ajaran al-Qur'an dan al-sunnah akan memungkinkan seseorang tidak hanya akrab dengan rincian perintah-perintah Islam serta penerapannya dalam kehidupan sehari-hari saja, melainkan sepenuhnya menghayati prinsip-prinsip dasar syari'ah serta berbagai sasarannya.

4. Keakraban dengan berbagai sumbangsih para ahli hukum dan pemikir Islam terdahulu (mujtahidin)

5. Keakraban dengan masalah-masalah serta kondisi zaman

6. Sifat dan tindak terpuji selaras dengan norma etika Islam ${ }^{41}$

Syarat yang dilontarkan Maududi untuk melakukan ijtihad dapat disimpulkan bahwa para anggota legislatif di Pakistan harus berasal dari kalangan ulama. Pandangan Maududi ini telah menempatkannya pada posisi para ulama tradisionalis. Tentu saja, kaum modernis sangat menentang gagasan itu karena mereka tidak mungkin dapat memenuhi persyaratan itu mengingat latar belakang pendidikan mereka. Di samping itu, sebagaimana telah diterangkan sebelumnya, bahwa kaum modernis berpendapat bahwa ijtihad bukanlah monopoli kaum 
ulama, tetapi kaum cendikiawan juga boleh dan bahkan harus berijtihad sesuai dengan bidang mereka masing-masing.

Maududi tidak menyangkal peranan ijtihad dalam hukum Islam, bahkan dia mengharuskan dilakukannya ijtihad, tetapi konsepsinya jelas berbeda dengan kaum modernis. Perbedaan itu disebabkan oleh perbedaan konsep mereka tentang al-Qur'an dan al-sunnah. Sebagaimana telah dikemukakan sebelumnya bahwa Maududi sangat literalis dalam memahami kedua sumber itu, sedang kaum modernis berpandangan liberal terhadap sumbersumber tersebut. Oleh karena itu, meskipun Maududi mengakui fleksibilitas hukum Islam, sikap literalismenya itu telah mengahambat perluasan ruang gerak ijtihad itu sendiri.

Yusuf al-Qardhawy memaparkan beberapa syarat dan peluang ijtihad kontemporer di masa sekarang, yang ia himpun dari berbagai pendapat ulama, yaitu:

Muhammad Rasyid Ridha dalam tafsir al-Manar mengemukakan sebagian pendapat para pakar ilmu ushul fiqh perihal syarat-syarat ijtihad. Rasyid Ridha menegaskan bahwa peluang ijtihad sekarang tidaklah lebih sulit bila dibandingkan usaha orang-orang yang hendak mencapai gelar-gelar yang tinggi dalam suatu disiplin ilmu menurut ulama-ulama zaman sekarang yang hidup di tengah-tengah negara maju seperti ilmu hukum, kedokteran dan filsafat. Sekalipun demikian, masih dapat dilihat bahwa mayoritas ulama yang masih taklid sebagai penghambat tercapainya ijtihad. ${ }^{42}$

Al-Hujwi al-Fasi menyatakan, "sesungguhnya materimateri ijtihad pada zaman sekarang lebih mudah dibandingkan pada zaman ulama-ulama terdahulu, sekiranya Allah berkenan memberi petunjuk."43

Pendapat senada juga diutarakan oleh Ibn Urfah, ia mengatakan ijtihad yang ada pada abad ke 14 ini lebih mudah dibandingkan ijtihad yang terjadi pada zaman dulu, karena para pakar di zaman sekarang ini jarang memberikan perhatian yang 
serius dalam bidang percetakan dan telah berhasil mencetak dan menerbitkan buku-buku yang berkaitan dengan masalah ijtihad. ${ }^{4}$

Yusuf al-Qardhawy mengomentari tentang kebolehan berijtihad dengan mengatakan bahwa ijtihad pada zaman sekarang ini tidak sekedar dibolehkan, bahkan merupakan fardhu kifayah yang dibebankan atas umat Islam. Seperti fardhu kifayah lainnya yang merupakan sendi urusan agama dan keduniaan. Artinya, apabila ada sebagian yang melaksanakan fardhu kifayah itu dan mengisi kekosongannya, maka gugurlah dosa dari semua umat. Apabila tidak ada yang melakukannya sama sekali, berarti seluruh umat berdosa. Hal ini terutama kepada pemerintah (penguasa), karena mereka bertanggung jawab menyiapkann orang yang bersedia melaksanakan fardhu kifayah yang bersifat umum. ${ }^{45}$

Mencermati pemikiran Yusuf al-Qardhawy, Rasyid Ridha, Al-Hujwi di satu sisi, mereka memiliki pandangan yang searah, di mana peluang ijtihad sekarang ini sangat mudah (terbuka) dan tidak membutuhkan syarat-syarat yang menyulitkan. Lain halnya dengan Maududi yang memberikan syarat cukup ketat bagi seseorang yang ingin melakukan sebuah ijtihad. Ketatnya syaratsyarat yang diajukannya ini, disebabkan Islam bagi Maududi bukan hanya sekedar aturan-aturan hidup bagi terselenggaranya sebuah pentas kehidupan yang harmonis. Tetapi merupakan darah yang menggerakkan seluruh organ kehidupan umat manusia di bawah bimbingan ketauhidan, yaitu Allah. Itulah sebabnya yang diperlukan dalam hidup bukan saja ijtihad (pengasahan intelektualitas yang cenderung pasif), tetapi juga jihad (sebuah usaha sosialisasi aktif kreativitas intelektual dan tindakan dalam realitas sosial dengan merujuk kepada al-Qur'an). Ringkasnya, orang-orang yang sama sekali tidak mahir bahasa alQur'an ataupun al-sunnah, bahkan yang sama sekali tidak memiliki wawasan mengenai tradisi Islam, tidak boleh berijtihad (bergelut dalam mencari solusi penafsiran al-Qur'an). Jika mereka diberi peluang untuk melicinkan jalannya pada satu atau lain 
sektor kehidupan kolektif, maka semuanya akan berakhir dengan malapetaka. Besok mungkin seseorang akan bangkit dan menyatakan bahwa tidak ada suatu profesi yang dinamakan profesi "ahli hukum (lawyer-hood)" dalam Islam, dan dengan demikian orang yang paling bodoh sekalipun memiliki hak yang sama untuk mengeluarkan keputusan-keputusan otoritatif mengenai masalah-masalah hukum, meskipun dia sama sekali buta mengenai masalah tersebut. Kemudian orang lainnya dapat saja berdiri dan menyatakan bahwa dalam Islam tidak ada "keinsinyuran" dan oleh karenanya dia merasa berhak untuk memecahkan masalah-masalah rekayasa teknik di negaranya, sebagaimana halnya seorang insinyur berbobot.

Sementara itu, dalam pandangan Muhammad Iqbal, ijtihad itu memang sangat dibutuhkan sekali, apalagi di zaman sekarang. Menurutnya ijtihad itu perlu diadakan secara ijtihad kolektif atau ijma'.46

Bila Abul A'la al-Maududi menginginkan suatu lembaga ijma' terdiri dari para cendekiawan dan para tokoh terkemuka (ulama), maka lain halnya dengan Iqbal. Iqbal menginginkan agar permusyawaratan yang diadakan dalam sebuah lembaga ijma' dalam rangka memutuskan suatu hukum, bukan hanya dihadiri oleh para ahli hukum dan cendekiawan, akan tetapi juga diwakili oleh orang-orang ahli di berbagai bidang. ${ }^{47}$

Menurut Iqbal, prinsip Islam adalah equilibrium; mengatur agama dan dunia; ibadah dan mu'amalah. Oleh sebab itu Iqbal tidak memutlakkan otoritas ulama di dalam lembaga ini. Sebaliknya ia mengharuskan diikutsertakannya "orang yang awam tentang hukum Islam tapi mempunyai pandangan tajam terhadap permasalahan masyarakat" di dalam lembaga ijma' tersebut. Inilah sebabnya Iqbal tidak menentukan syarat keulamaan an sich pada orang yang akan duduk di lembaga ijma'. Hukum Islam bukan hanya mengatur satu atau dua masalah kehidupan manusia saja, melainkan kompleks. Oleh sebab itu, perbincangan hukum Islam dalam lembaga ini tidak dapat 95 Al-Fikra: Jurnal Ilmiah Keislaman, Vol.3, No.1, Januari-Juni 2004 
dipisahkan dari aspek-aspek kehidupan lainnya. Di dalam lembaga ijma' ini harus terlibat pula para ahli dari berbagai bidang seperti sosial, politik, ekonomi, budaya, kedokteran dan sebagainya. ${ }^{48}$

Meskipun, terdapat sedikit kesenjangan, pada prinsipnya antara Maududi dan Iqbal dalam merumuskan (memberi formulasi) tentang sebuah keputusan ijtihad, masih dapat diambil suatu jalinan (benang merah) yang dapat menjembatani dualisme pemikiran mereka. Iqbal sebenarnya sepakat dengan argumen yang ditawarkan Maududi, di mana para pakar (ulama) dan cendekiawanlah yang berkompeten untuk duduk dalam suatu majelis ijma' dalam memutuskan hukum. Namun dalam pandangan Iqbal, tidak ada salahnya menerjunkan orang-orang awam dari berbagai jenis (bidang) untuk ikut serta mengikuti jalannya persidangan. Mereka boleh mengikuti dan mendengarkan semua keputusan para cendekiawan (ulama) dan tidak diberi hak untuk berkomentar, kecuali dalam batas-batas yang masih wajar dalam kapasitas mereka. Apa yang dikhawatirkan oleh Maududi akan munculnya gebrakangebrakan di masa depan tentang keberanian orang perorang dalam mengambil suatu kebijakan hukum melalui ijtihadnya sendiri-sendiri, pantas untuk dikhawatirkan, karena bukan tidak mungkin akan banyak muncul problem-problem yang lebih rumit dari sekarang yang membutuhkan penyelesaian secara mendadak. Bila orang-orang awam (yang tidak berkomperten) diterjunkan dalam sidang ijma', maka secara tak langsung mereka merasa berhak untuk menegaskan pendapatnya walau ilmu bahasa dan wawasan al-Qur'annya sama sekali nihil.

Dalam melakukan ijtihad, Yusuf al-Qardhawy memberikan beberapa komentarnya tentang kode etik ijtihad, yaitu:

1. Tidak ada ijtihad tanpa mencurahkan kemampuan

2. Tidak ada ijtihad dalam masalah-masalah yang qat'i

3. Tidak boleh menjadikan dzanni sebagai qat'i

4. Menghubungkan antara fiqh dan hadis

96 Al-Fikra: Jurnal Ilmiah Keislaman, Vol.3, No.1, Januari-Juni 2004 
5. Waspada agar tidak tergelincir oleh tekanan realita

6. Mengantisipasi pembaharuan yang bermanfaat

7. Tidak mengabaikan semangat zaman dan kebutuhannya

8. Transformasi menuju ijtihad kolektif (jama'i)

9. Bersikap lapang dada terhadap kekeliruan mujtahid ${ }^{49}$

Kesembilan kode etik ijtihad yang ditawarkan Yusuf alQardhawy merupakan kode etik yang sudah mewakili beberapa keinginan Maududi dalam persyaratan ijtihad. Akan tetapi dalam konsep Maududi, kode etik ijtihad harus diperjelas lagi secara faktual (tidak menimbulkan interpretasi baru), sebagaimana Yusuf al-Qardawy kelihatan masih kurang tegas dalam memformulasikan sembilan kode etik yang ditawarkannya.

Dari rangkaian dan paparan tentang kodifikasi hukum Maududi, pada intinya ia menginginkan bahwa Allah SWT dan Rasul-Nya merupakan Undang-Undang tertinggi bagi orangorang mukmin, tidak ada pilihan lain kecuali patuh dan taat kepada-Nya. Undang-Undang ini perlu direalisasikan ke dalam bentuk formulasi hukum yang terkodifikasi secara teratur berdasarkan tema-tema serta pembagian-pembagian keputusan hukum, seperti hukum internasional, hukum kemiliteran, peraturan-peraturan yang bersangkutan dengan jawatan-jawatan, hukum-hukum kesaksian, ketentuan-ketentuan peradilan dan hukum-hukum yang berkenaan dengan setiap segi kehidupan ekonomi, demikian pula hukum-hukum ibadat, hukum-hukum perkawinan, perceraian, warisan dan hukum-hukum kekeluargaan, yang semuanya ini telah disusun oleh Imam Abu Yusuf dan Muhammad ibn Hasan as-Syaibani. ${ }^{50}$

Muwaffaq Ibn Ahmad al-Makki (w. 568 H/1172 M) mengatakan bahwa Abu Hanifah telah menyusun mazhabnya dengan cara permusyawaratan di kalangan para muridnya, tidak pernah ia bertindak sebagai diktator melangkahi mereka. Hal ini sebagai manifestasi kesungguhannya dalam agama dan ketulusannya yang sangat terhadap Allah, Rasul-Nya serta kaum mukminin. Maka ia pun melemparkan masalah demi masalah 
kepada mereka agar dapat membahasnya dan ia dapat mendengar pendapat-pendapat mereka. Setelah itu, ia mengucapkan pendapatnya sendiri dan mendiskusikannya selama sebulan penuh atau lebih, sehingga mantaplah salah satu kesimpulan berkenaan dengan masalah tersebut. Kemudian, kesimpulan itu dicatat oleh al-Qadhi Abu Yusuf sebagai suatu pokok persoalan, demikian seterusnya sehingga ia mencatat seluruh pokok persoalan dan terciptalah, dengan cara itu, mazhab Abu Hanifah. ${ }^{51}$

Apa yang dipaparkan al-Makki di atas, pada prinsipnya Maududi juga ambil bagian dalam mengkaji arah pemikiran Abu Hanifah serta Abu Yusuf (notulis/sekretaris setia Abu Hanifah). ${ }^{52}$ Maududi banyak mengadopsi tata cara pengumpulan informasi dan kiat penetapan hukum yang diambil Abu Hanifah bersama permusyawaratan dengan para muridnya. Ultimate goal dari semua pengumpulan dan keputusan hukum yang dikoleksi Abu Hanifah melahirkan kodifikasi hukum yang dikenal dengan mazhab Abu Hanifah yang telah memiliki pengikut di berbagai penjuru dunia.

Beranjak dari pemikiran dan keberhasilan Abu Hanifah, serta bertolak dari semua fenomena dan kejadian terbaru serta perubahan wajah dunia, Maududi menginginkan adanya suatu formulasi hukum baru yang terkodifikasi secara baik dan teratur. Apa yang dibuat oleh Abu Hanifah, boleh jadi merupakan gebrakan yang sangat memuaskan dunia Islam dan menjadi rujukan umat dalam mengaplikasikan hukum bagi para pelanggar hukum (terdakwa). Akan tetapi sebagimana layaknya perubahan dan akselerasi tuntutan global, tentunya ketetapan hukum bagi segenap lapisan masyarakat harus dikondisikan pula dengan berbagai modifikasi yang dituntutnya. Untuk itu, dengan membengkaknya gejala-gejala moralitas, menurunnya kesadaran akan menjalankan syariat serta terjadinya masalah-masalah terbaru, membuat posisi hukum Islam cukup tersudut, karena 
tidak ditemukannya hukum yang pasti dalam menentukan kebijakan.

Hukum-hukum itu tentunya terkait dengan semua aktivitas manusia dan kehidupan umat manusia di dunia. Baik aktivitas menyangkut ekonomi, pendidikan, kemiliteran, ibadah, perkawinan, peradilan, perceraian, pewarisan, sengketa tanah, masalah-masalah peternakan/pertanian, dan lain sebagainya, yang semua ini membutuhkan suatu format atau kodifikasi hukum dalam sebuah perundang-undangan yang disarikan dari al-Qur'an dan al-hadis. Penafsiran-penafsiran ayat-ayat al-Qur'an dan hadis ini tentunya menginginkan undang-undang tertulis berbentuk penafsiran, qiyas, ijtihad (istihsan) yang diinterpretasikan dari berbagai ayat atau hadis yang masih dzanni, dimusyawarahkan secara ijma' oleh para tokoh ulama (cendekiawan) melalui suara terbanyak. Selanjutnya diformat atau dirancang sebagai undang-undang modern dengan interpretasi berbagai dalil atau bukti yang ada, kemudian diformat sedemikian rupa sehingga memunculkan berbagai bentuk hukum seperti: Hukum Pembuktian, Hukum Acara Perdata, KUHP, Kitab Hukum Acara Pidana, dan sebagainya sebagaimana bentuk formulasi hukum yang ada di Indonesia.

\section{IV}

\section{Reformasi Pendidikan Hukum}

Pendidikan merupakan usaha yang dilakukan untuk meningkatkan mutu dan kekokohan suatu bangsa, di mana dalam realisasinya dibutuhkan berbagai planning yang matang demi mengangkat derajat dan martabat kehidupan manusia. Manusia sebagai makhluk yang berperadaban, sudah barang tentu mempunyai kecenderungan untuk merubah diri menuju suatu tuntutan idealitas yang kelak dapat mempertinggi kedudukannya di mata publik. 
Melihat berbagai fenomena dan status sosial manusia yang tak jelas, khususnya di negara Pakisan, banyaknya kebejatan moral serta nuansa-nuansa yang tidak sedap dipandang mata, serta ketidakjelasan aplikasi hukum dalam kehidupan umat, mendorong Abul A'la al-Maududi tergerak untuk mereformasi pendidikan hukum di Pakistan.

Reformasi pertama yang dicetuskan Maududi sebagai langkah awal dalam upaya aplikasi pendidikan hukum ialah memutuskan pengetahuan bahasa Arab sebagai pra-syarat untuk memasuki akademi hukum. ${ }^{53}$ Langkah ini diambilnya, karena untuk memberikan pemahaman kepada masyarakat luas tentang masalah akidah, akhlak, ibadah dan sebagainya. Mereka harus mengetahui seluk beluk bahasa Arab untuk kegunaan menangkap atau memahami firman Tuhan yang memang diturunkan melalui bahasa Arab. Bahasa Arab penting dipelajari sedini mungkin karena ia merupakan bahasa pengantar di dunia Islam sekaligus sebagai bahasa beribadat kepada Sang Khaliq.

Bahasa Arab menurut Maududi, harus dijadikan sebagai bahasa dunia Islam, karena suatu wawasan yang mendalam atas ayat-ayat al-Qur'an atau hukum Islam hanya dapat dimungkinkan jika menguasai bahasa pengantar dari al-Qur'an itu sendiri. AlQur'an sebagai bahasa agama juga harus dijadikan sebagai bahasa pengkajian ilmu pengetahuan (scientific) dan hukum (law). Penggunaan bahasa Arab, khususnya di kalangan siswa/mahasiswa Akademi harus dijadikan sebagai pedoman (rujukan) semua keilmuan dan keputusan hukum yang akan diambil dalam sebuah kepastian hukum.

Ide Maududi tentang pentingnya penekanan bahasa Arab sebagai pra-syarat bagi mahasiswa yang akan memasuki akademi hukum, sangat didukung oleh Muhammad al-Gazali (guru dari Yusuf al-qardawy). ${ }^{54}$ Al-Gazali menganjurkan agar lembagalembaga pendidikan bagi para anak sekolah memasukkan kurikulum bahasa Arab sebagai mata pelajaran wajib yang diajarkan di setiap jenjang. Dengan mempelajari bahasa Arab, 100 Al-Fikra: Jurnal Ilmiah Keislaman, Vol.3, No.1, Januari-Juni 2004 
diharapkan akan berdampak positif bagi pemahaman dan penemuan makna-makna dan kandungan ayat al-Qur'an yang sampai sekarang masih butuh interpretasi-interpretasi yang dalam. ${ }^{55}$ Beribu-ribu rahasia yang tersirat masih banyak yang belum ditemukan di dalam al-Qur'an. Jika umat Islam tidak dididik untuk mengasah dan mempelajari bahasa Arab, maka dikhawatirkan khazanah ilmu yang ada di dalamnya justru dikuasai oleh orang-orang di luar Islam yang mulai menjejaki ilmu-ilmu dan kandungan yang ada di dalamnya, sebagaimana para orientalis juga berkecimpung mendalaminya.

Gebrakan Maududi untuk mewajibkan mengikuti pendalaman materi bahasa Arab selama setahun sebelum berkecimpung di dalam akademi hukum di Pakistan, pantas diperhitungkan. Idenya ini paling tidak akan membuat sebuah gebrakan bagi para siswa/mahaiswa yang akan memasuki akademi hukum merasa tertantang dan tidak sebatas kemauan belaka. Dengan tantangan yang demikian, mereka paling tidak berusaha mempersiapkan diri dan siap bertempur dalam mengarungi dan meniti seluk beluk hukum serta interpretasiinterpretasinya lebih mendalam ketika duduk di jenjang akademi.

Langkah kedua yang ia ajukan, sejalan dengan pengajaran bahasa Arab adalah mengkaji al-Qur'an dan hadis sebelum mulai pendidikan mereka di bidang hukum. ${ }^{56}$ Langkah ini sejalan dengan penerapan pengetahuan bahasa Arab yang kajiannya sama-sama bersumber dari bahasa Arab.

Dalam mengkaji al-Qur'an dan hadis, harus benar-benar diarahkan kepada penelusuran ayat dan makna hadis yang sesuai dengan penafsiran kontemporer. Sebelum memasuki materi hukum yang berisikan figh (mu'amalah), para mahasiswa akademi hukum harus mengedepankan al-Qur'an daripada pemikiran fiqh (mazhab) yang telah membentuk opini intelektualnya sebelumnya. Kesalahan selama ini adalah mengenalkan hukum-hukum fiqh yang diambil dari salah satu mazhab, sehingga anak merasa satu-satunya jalan yang condong 101 Al-Fikra: Jurnal Ilmiah Keislaman, Vol.3, No.1, Januari-Juni 2004 
kepada aktivitas yang sesuai dengan syariat Islam, semata-mata hanya diwakili oleh pemikiran mazhab yang telah lama ditransfer oleh orang tua mereka jauh-jauh sebelum memasuki lembaga pendidikan (sekolah).

Mempelajari materi-materi serta pendalaman makna alQur'an tidak akan pernah berakhir sesuai dengan derasnya perkembangan wacana dunia serta hegemoni peradaban yang semakin menunjukkan ketidakjelasan. Seiring dengan itu, diskusidiskusi ilmiah tentang penuntasan permasalahan-permasalahan hidup mutlak dibutuhkan dalam menyahuti problema hidup yang semakin menantang.

Seseorang yang telah lulus dalam ujian atau tes bahasa Arab di akademi, selanjutnya akan mengikuti perkuliahan hukum, di mana menurut Maududi, para mahasiswa telah siap dengan segala kondisinya untuk mendalami ayat-ayat al-Qur'an yang berhubungan dengan hukum. Baik ditinjau dari kajian fiqh, ushul fiqh, moral, qiyas, ijma' maupun berbagai fenomena dan tinjauan hukum lainnya. Semua ini saling berkait dan tak bisa dipisahkan.

Reformasi ketiga Maududi dalam rangka reformasi pendidikan hukum adalah menekankan kurikulum akademi hukum kepada 3 (tiga) mata kuliah utama yaitu:1. Dasar-dasar yurisprudensi Islam, 2. Sejarah yurisprudensi Islam, dan 3. Fiqh (kajian netral atas semua mazhab fiqh utama). ${ }^{57}$

Ketiga mata kuliah ini menurut Maududi, adalah kunci utama yang akan dapat menghantarkan para mahasiswa akademi hukum benar-benar memahami hukum-hukum fiqh serta hukumhukum semua perbuatan dan aktivitas manusia. Dasar-dasar atau prinsip-prinsip hukum Islam penting untuk diketahui para mahasiswa karena ia merupakan landasan paling menentukan dalam segenap aktivitas dan cakrawala manusia. Jika prinsipprinsip tersebut tidak dipahami secara akurat, tentunya mereka tidak akan dapat menerapkan hukum-hukum ini kepada masalah- 
masalah baru yang selalu muncul setiap hari yang terus menerus menciptakan situasi-situasi terbaru.

Untuk mengatasi permasalahan-permasalahan yang baru muncul, maka sejarah fiqh lah yang harus dikaji ulang kembali untuk mengetahui keputusan hukum yang akan diambil di kemudian hari. Tanpa mengetahui sejarah, maka seseorang akan mengalami rintangan dan kesulitan yang cukup melelahkan dalam mengambil kebijakan (keputusan) hukum. Sejalan dengan itu, analogi juga terasa mandeg dan menerawang, tak tahu dari mana akan memulai sebuah gebrakan yang sesegera mungkin dilaksanakan.

Sejarah hukum dunia Islam membuktikan bahwa pemerintahan Islam telah dilanda kekacauan hukum. Selama satu abad penuh, umat tidak memiliki konstitusi yang dapat diandalkan sehingga semua mahkamah negara dapat berpegang kepadanya dan mengeluarkan suatu keputusan sesuai dengan asas-asas yang dikeluarkannya. Oleh sebab itu, dengan mengetahui sejarah, paling tidak arah dan tujuan ditegakkannya hukum dapat tersosialisasi secara baik. Justru sebaliknya, bila tidak mengenal sejarah masa lalu, maka produk hukum yang akan dikeluarkan akan terlihat kaku dan kurang menyentuh kepuasan lapisan masyarakat tertindas.

Mata kuliah ketiga yang kelak dapat menghantarkan kesuksesan bagi seorang penegak hukum adalah mempelajari fiqh secara mendalam dan penuh keseriusan (ketelitian). Mazhabmazhab fiqh yang berkembang, tidak boleh diterima begitu saja, dalam arti taklid buta, tanpa mengetahui landasan yang mendasarinya. Selanjutnya menurut Maududi, semua mazhabmazhab fiqh yang beredar di semua lapisan masyarakat Islam tidak boleh serta merta dilegitimasi dan diberikan angin segar untuk mengembangkan pemahamannya kepada masyarakat awam. Semua mazhab fiqh yang ada, harus dipandang secara netral tanpa ada yang diidolakan sebagai rujukan utama dalam pelaksanaan ibadah sehari-hari.

103 Al-Fikra: Jurnal Ilmiah Keislaman, Vol.3, No.1, Januari-Juni 2004 
Langkah keempat (reformasi keempat) adalah bersama-sama dengan reformasi kurikulum pendidikan hukum, diikuti pula oleh penataran moral dan pembinaan akhlak mahasiswa. 58

Penataran moral sangat penting dilakukan bagi segenap para siswa di akademi hukum, karena dalam realitas yang ada di masa menggelindingnya proses pendidikan, ketika masa kehidupan Maududi, banyak di kalangan guru akademi yang sama sekali tidak mementingkan aspek afektif (perilaku moral/akhlak) pendidikan, mereka umumnya hanya mengandalkan aspek kognitif (keilmuan) belaka sehingga wajar saja kalau siswa atau mahasiswa di akademi tersebut hanya belajar hukum sebatas teori tanpa mempunyai niat dan antusias tinggi untuk mengaplikasikan ilmunya secara nyata dan berlandaskan hukum yang dipelajarinya.

Hukum-hukum yang dipelajari para siswa/mahasiswa di akademi hukum, biasanya harus berpatokan kepada al-Qur'an. Berbagai gejolak permasalahan yang membutuhkan penyelesaian hukum tentunya juga dipengaruhi oleh alam, karena alam adalah tempat tinggal dan kehidupan bagi manusia. Barang siapa yang merusak alam, maka bencana akan menimpa manusia. Sebaliknya manusia yang menjaga alam dengan seutuhnya, pasti akan terhindar dari mara bahaya.

Fazlur Rahman memandang bahwa ajaran dasar al-Qur'an tentang alam mencakup tiga hal, yaitu:

1. bahwa ia merupakan sebuah kosmos

2. bahwa ia merupakan suatu tatanan yang berkembang yang dinamis

3. bahwa ia bukanlah suatu permainan yang sia-sia, tetapi harus ditanggapi secara serius; manusia harus mempelajari hukumhukumnya, yang merupakan bagian dan perilaku Tuhan, dan menjadikannya sebagai panggung dari aktivitas manusia yang punya tujuan. ${ }^{59}$

Oleh sebab itu menurut Rahman, alam semesta bukanlah tempat kesenangan yang telah "siap pakai" untuk manusia, 104 Al-Fikra: Jurnal Ilmiah Keislaman, Vol.3, No.1, Januari-Juni 2004 
sehingga mereka tidak mengalami kesulitan. Untuk itu Allah memberikan akal pikiran dan menyerahkan amanat kepada manusia untuk mengelola alam semesta. Menurutnya, hakikat amanat itu adalah menemukan dan menguasai hukum-hukum Tuhan dalam alam semesta dan kemudian menggunakannya di bawah naungan inisiatif moral manusia dalam rangka menciptakan tata dunia yang baik. Aktivitas manusia menjalankan amanat inilah yang merupakan tujuan penciptaan manusia di bawah bimbingan etika dan moral al-Qur'an.

Dalam kesempatan lain, Rahman juga mengungkapkan bahwa tujuan al-Qur'an dalam tatanan sosial adalah untuk menciptakan suatu sistem kemasyarakatan yang etis dan egalitarian (sama). ${ }^{60}$ Oleh sebab itu Rahman memandang hukum Islam bersifat dinamis dan harus dikembangkan sesuai dengan perkembangan zaman.

Pemikiran Rahman yang cukup dinamis, tampaknya memiliki akar pemikiran yang searah dengan Maududi, karena dalam pandangan Maududi, alam itu juga tidak terlepas dari realitas hukum yang akan dijalankan. Hukum-hukum alam merupakan bagian dari perilaku Tuhan yang harus dijawab dan dilestarikan. Oleh sebab itu, bagi para guru atau pendidik di Akademi-Akademi Hukum harus dapat menerapkan pendidikan yang disejajarkan dengan kajian-kajian hukum alam, selanjutnya diaplikasikan ke dalam berbagai metode pengajaran hukum dengan cara mengorkestra berbagai taktik dan pendekatan yang kelak dapat merubah akhlak dan moralitas mereka dalam menerapkan hukum secara murni tanpa peduli gangguangangguan yang sifatnya negatif.

\section{Reformasi Sistem Peradilan}

Ide reformasi sistem peradilan yang ada dalam benak Maududi berkisar kepada dua hal berikut:

105 Al-Fikra: Jurnal Ilmiah Keislaman, Vol.3, No.1, Januari-Juni 2004 
The first problem which deserves attention is the legal profession which is one of the worst and probably the greatest banes of the present judicial system. From the moral point of view not a single argument can be put forward in its favour. ${ }^{61}$ In order to make the country's judicial system conform to the Islamic standards, another important reform is needed, and that is the abolition of the court-fee. ${ }^{62}$

Ide Pertama menyatakan bahwa profesi pengacara merupakan rintangan terburuk dan bahkan mungkin terbesar dari sistem peradilan. Ide Kedua diarahkan pada penyelaraskan sistem pengadilan negara ini dengan standar-standar Islam, diperlukan reformasi penting dengan menghapuskan honor pengadilan.

b. Profesi pengacara dalam sistem peradilan di Pakistan jangan dijadikan sebagai alternatif (ajang/laga pengkaburan fakta) demi melegitimasi pendapatnya

Ide ini dilontarkan, melihat lemahnya sistem hukum yang ada di Pakistan. Para pengacara di pengadilan umumnya hanya memperjuangkan nasib kliennya demi uang dan kekayaan. Pengacara hanya berlomba-lomba mengumpulkan dan bersedia membela klien mati-matian demi materi (money). Bila klien (terdakwa/tertuduh) tidak mampu membayarnya dengan beberapa standar pembayaran yang telah ada, maka klien harus mencari pengacara yang standarnya lebih murah. Dan bila ternyata klien juga kalah dalam persidangan, maka pengacara setelah selesai persidangan tidak akan peduli lagi dengan keadaan terdakwa, pengacara juga tidak akan memperhatikan kapan kliennya akan dibebaskan dari ikatan tirani (penjara). ${ }^{63}$ Akan tetapi bila kliennya masih berhubungan dengan pengacaranya, maka boleh jadi ia juga akan rajin menjenguk serta memberikan harapan-harapan yang menggiurkan. Demikianlah kondisi dan 
keberadaan hukum yang ada di negara-negara miskin dan negara berkembang pada umumnya.

Melihat kondisi dan fakta yang ada, kenyataannya sistem hukum di Pakistan masih sangat lemah dan tidak memperdulikan nilai-nilai dan hak azasi manusia yang notabene adalah keadilan.

Para hakim juga merasa terkontrol oleh kedua belah pihak dalam memutuskan suatu perkara. Hal ini lah yang melandasi Maududi untuk mengomentari pentingnya kebebasan (free will/act) bagi seorang hakim dalam memutuskan perkara, sebagaimana kebebasan ini juga telah dideklarasikan di masa kekhalifahan yang benar atau khilafa al-rasyidah, di mana hakim itu pada hakikatnya memiliki kebebasan dari segala ikatan dan tekanan, kecuali ketakwaan kepada Allah, ilmu dan nurani mereka. Tidak seorang pun, betapa tinggi kedudukannya dan besar wibawanya, berani ikut campur dalam tindakan mahkamah sedemikian rupa, sehingga seorang hakim dapat menjatuhkan keputusan yang merugikan para khalifah itu sendiri, bahkan dalam prakteknya seringkali membuat keputusan melawan mereka. Namun ketika sistem khilafah telah berubah menjadi sistem kerajaan, prinsip ini tidak lagi berjalan dengan mulus, bahkan sedikit demi sedikit makin hilang, demikian juga halnya dengan kondisi pengadilan (para hakim) di Pakistan di masa Abul A'la al-Maududi.

Di masa Maududi, perkara-perkara yang para penguasa dan para raja terlibat di dalamnya, dengan alasan-alasan politis atau pribadi, tidak lagi memberi kebebasan kepada mahkamahmahkamah untuk mengeluarkan keputusan-keputusan yang adil dan tepat, sehingga keadilan menjadi sulit sekali dicapai dalam perkara-perkara yang diajukan, para gubernur, para komandan, bahkan antek-antek penguasa dan para sahabat dekat para pejabat. Hal ini pula merupakan sebab utama bagi sejumlah ulama yang mulia menolak jabatan dalam peradilan. Seorang ulama yang bersedia duduk di kursi kehakiman yang ditunjuk oleh para penguasa selalu dipandang oleh rakyat banyak dengan 107 Al-Fikra: Jurnal Ilmiah Keislaman, Vol.3, No.1, Januari-Juni 2004 
pandangan yang penuh keraguan dan kebimbangan. Tindakantindakan keterlaluan dan penuh aniaya yang dilakukan lembaga Eksekutif terhadap lembaga Yudikatif telah melewati batas, sehingga seorang wali negeri mempunyai kekuasaan untuk memecat para hakim atau mengangkat mereka, padahal kekuasaan seperti ini tidak pernah terjadi di masa khilafah alrasyidah.

Fenomena-fenomena seperti di atas, dalam pandangan Maududi harus diberantas secepat mungkin melalui transformasi kebenaran dan keberanian menunjukkan fakta yang sebenarnya di kalangan hakim. Para pengacara juga sedini mungkin harus dikoordinir keberadaannya, jangan terpengaruh oleh uang suap yang kelak menjerumuskannya ke dalam neraka. Di sinilah letak kebebasan hakim yang sebenarnya, yaitu bebas menentukan keputusannya secara transparan tanpa takut dengan adanya ancaman dan balas dendam yang akan menimpa jati diri dan profesinya.

c. Pemberantasan Prilaku Sogok Menyogok

Di negara-negara miskin dan negara berkembang lainnya di dunia, seringkali keadilan ditegakkan di atas benang basah. Ini artinya keadilan bisa disimpangsiurkan melalui interpretasi negatif perundang-undangan hukum yang ada. Permainan dan kelihaian pengacara dalam hal ini sangat dibutuhkan untuk memperlancar susksesnya persidangan dan kemenangan bagi pihak yang memiliki sejumlah uang. Hakim-hakim yang memiliki tekad dan niat untuk mengadili terdakwa secara bijaksana, boleh jadi di tengah jalan menyimpang dari tekad semula. Ini dikarenakan adanya ancaman dan sogokan yang menggiurkan, sehingga kebenaran yang semula diharapkan malah berbalik menjadi pengkaburan data dan fakta-fakta. Hal ini pula yang menjadi momok dalam dunia peradilan yang sedini mungkin harus dihapuskan. ${ }^{64}$

Sistem peradilan dengan cara menyogok seperti ini menurut Maududi, belum dikenal di dunia Pakistan. Namun 108 Al-Fikra: Jurnal Ilmiah Keislaman, Vol.3, No.1, Januari-Juni 2004 
ketika penjajahan Inggris mulai merambah ke negara ini, maka banyak muncul sistem-sistem penegakan hukum yang tidak sehat, yang imbasnya mengalir kepada orang-orang miskin yang tidak mampu menuntut keadilan dengan harga yang cukup mahal. ${ }^{65}$

Mencermati fenomena semacam ini, dalam rangka menegakkan keadilan secara murni dan bijaksana, maka Maududi menawarkan dua solusi penghapusan honor pengadilan. Honor pengadilan tidak perlu dibayar, tetapi biaya yang dikeluarkan persidangan/pengadilan dapat dibayar melalui:

1. Di bawah dispensasi Islam, maksudnya lembaga pengadilan yang sangat mapan dewasa ini tidak diperlukan lagi. Para pengacara yang hidup dengan pemutarbalikan fakta di persidangan juga akan berkurang peranannya. Panjangnya perkara akan dipersempit sehingga tidak ada waktu yang siasia. Para hakim yang akan mengadili seseorang diawasi secara ketat, dan tidak dibolehkan menjumpai orang-orang yang terlibat dalam suatu perkara yang akan disidangkan. Para polisi dalam hal ini juga dilibatkan untuk menjaga para hakim serta ditempatkan di kawasan yang dijaga ketat oleh aparat, sehingga sebelum disidangkannya perkara sampai selesainya perkara, orang-orang yang terlibat dalam sebuah kasus tidak akan bisa bertemu sang hakim.

2. Diberikan denda kepada orang-orang yang terlibat menyogok, di mana dalam hal ini orang-orang yang terlibat suatu kasus di pengadilan serta ketahuan memberikan uang suap kepada salah seorang hakim, harus didenda berdasarkan berat ringannya sebuah kasus yang akan diputuskan. Demikian pula seseorang yang telah mendapat putusan dari pengadilan sehingga memperoleh keuntungan dalam bentuk sejumlah uang dapat dikenakan pajak sesuai dengan tarif yang telah ditetapkan. ${ }^{66}$

Sejalan dengan itu bila dikaitkan dengan pemikiran Maududi tentang adanya lembaga Legislatif, Eksekutif dan Yudikatif, maka Maududi menyatakan bahwa lembaga Legislatif 109 Al-Fikra: Jurnal Ilmiah Keislaman, Vol.3, No.1, Januari-Juni 2004 
merupakan lembaga penengah dan pemberi fatwa (ahl al-hall wa $a l-$ - $\left._{q} q d\right)$. Menurutnya, suatu negara yang didirikan dengan dasar kedaulatan de jure Tuhan tidak dapat melakukan legislasi yang bertolak belakang dengan al-Qur'an dan al-sunnah, sekalipun konsensus rakyat menuntutnya. Oleh karenanya, dari pandangan ini diketahui bahwa lembaga Legislatif sebagaimana dalam konsep pemikiran Maududi, tidak berhak membuat perundangundangan yang bertentangan dengan tuntunan-tuntunan Tuhan dan Rasul-Nya, dan semua cabang legislasi. ${ }^{67}$ Lain halnya dalam konteks negara Indonesia, lembaga legislatif di Indonesia, yang bukan merupakan negara Islam, maka para pengambil dan pembentuk perundang-undangan agak lebih leluasa dalam membuat perundang-undangannya tanpa rujukan mendalam terhadap tuntutan-tuntutan sebagaimana dalam formulasi yang ditawarkan Maududi.

Sedangkan lembaga Eksekutif yang dijalankan oleh Presiden di berbagai negara non-Islam pada umumnya, diganti dengan Ulil amri atau Umara'. Berdasarkan al-Qur'an dan hadis, umat Islam diperintahkan untuk mentaatinya dengan syarat bahwa lembaga eksekutif ini menaati Tuhan dan Rasulullah saw. serta menghindari dosa dan pelanggaran, sebagaimana firmanNya Q.S. al-Syu'ara: 152-152: "Dan janganlah kamu mentaati perintah orang-orang yang melampaui batas, yang membuat kerusakan di muka bumi dan tidak mengadakan perbaikan".

Sedangkan lembaga Yudikatif yang digambarkan Maududi bermakna sebuah pengakuan atas kedaulatan de jure dari Tuhan Yang Maha Kuasa, yang dalam terminologi hukum Islam dikenal dengan qadha.68 Ketika Islam menegakkan negaranya sesuai dengan prinsip-prinsip abadi-Nya, Rasulullah sendirilah yang menjadi hakim pertama negara tersebut, dan beliau yang melaksanakan fungsi ini dengan sangat selaras dengan Hukum Tuhan, sebagaimana Q.S. al-Maidah: 148: "Maka putuskanlah perkara mereka menurut apa yang Allah turunkan dan janganlah kamu

110 Al-Fikra: Jurnal Ilmiah Keislaman, Vol.3, No.1, Januari-Juni 2004 
mengikuti hawa nafsu mereka dengan meninggalkan kebenaran yang telah datang kepadamu".

Dalam konteks Indonesia, yang mengemban gelar Yudikatif adalah para jaksa, hakim dan Mahkamah Agung, yang berusaha menjalankan semua hukum yang disarikan dari Kitab Perundang-Undangan resmi, baik hukum perdata, pidana, KUHP dan sebagainya.

Al-Maududi menjelaskan tentang penegakkan hukum Islam ke dalam program kehidupan Islam yang integral. Para pendukung negara syari'at bangsa Pakistan punya komitmen pada al-Qur'an dan al-Sunnah sebagai sumber hukum yang menjiwai namun berbeda dengan memegangi fiqh (yurisprudensi) Islam. Sedangkan kaum absolutis dan al-Maududi melihat keseluruhan syari'at dan yurisprudensi dapat diterapkan secara langsung dalam kehidupan. Penerapan dan penegakan hukum Islam yang dimaksudkan al-Maududi dapat dilihat pada empat poin yang perlu segera dibentuk, yaitu akademi hukum, kodifikasi hukum Islam, reformasi pendidikan hukum Islam, dan reformasi sistem peradilan.

Pertama, akademi hukum. Upaya pendirian Akademi Hukum yang dimaksudkan bukan hanya semata-mata penterjemahan kitab belaka, tetapi mengadakan suatu forum kajian lebih lanjut dalam menginterpretasikan kandungan perundang-undangan yang dapat ditinjau kembali pemahamannya melalui berbagai dimensi, baik dimensi yang dikaitkan dengan fenomena modern, dimensi penyuntingan kembali makna sebuah pasal atau ayat, ataupun dimensi yurisprudensi yang disesuaikan dengan kebutuhan tuntutan kemanusiaan.

Kedua, kodifikasi hukum Islam. Maududi menginginkan adanya lembaga cendekiawan Islam dan para ahli pemikiran 111 Al-Fikra: Jurnal Ilmiah Keislaman, Vol.3, No.1, Januari-Juni 2004 
hukum modern yang dapat melakukan kodifikasi hukum Islam dalam bab demi bab, pasal demi pasal dan ayat demi ayat. Kodifikasi hukum Islam diambil berdasarkan empat sumber, yaitu: perintah yang jelas dari al-Qur'an, perintah yang jelas atau larangan dari Rasulullah saw. (hadis), penafsiran, inferensi, qiyas (analogi), ijtihad (istihsan) yang telah mencapai ijma' di kalangan umat atau merupakan keputusan mayoritas ulama yang telah diakui, dan Ijma' atau keputusan mayoritas mengenai persoalan penafsiran, inferensi, qiyas dan dalil hukum lainnya.

Ketiga, reformasi pendidikan hukum. Reformasi pendidikan hukum yang dilakukan Maududi dapat dilihat pada beberapa langkah, yaitu memutuskan pengetahuan bahasa Arab sebagai prasyarat untuk memasuki akademi hukum; mengkaji alQur'an dan hadis sebelum mulai pendidikan mereka di bidang hukum; menekankan kurikulum akademi hukum kepada 3 (tiga) mata kuliah utama yaitu: 1) Dasar-dasar yurisprudensi Islam, 2) Sejarah yurisprudensi Islam, dan 3) Fiqh (kajian netral atas semua mazhab fiqh utama); dan bersama-sama dengan reformasi kurikulum pendidikan hukum, diikuti pula oleh penataran moral dan pembinaan akhlak mahasiswa.

Keempat, reformasi sistem peradilan. Ide reformasi sistem peradilan yang ada dalam benak Maududi berkisar kepada dua hal, yaitu: a) profesi pengacara yang merupakan rintangan terburuk dan bahkan mungkin terbesar dari sistem peradilan, b) untuk menyelaraskan sistem pengadilan negara ini dengan standar-standar Islam, diperlukan reformasi penting dengan pemberantasan suap.

\section{DAFTAR KEPUSTAKAAN}

Ahmed, Ishtiaq, The Consept of an Islamic State: An Analysis of the Ideological Controversy in Pakistan, New York: St. Martin's Press, 1987

112 Al-Fikra: Jurnal Ilmiah Keislaman, Vol.3, No.1, Januari-Juni 2004 
Ali, Mukti, Alam Pikiran Islam Modern Di India dan Pakistan, Bandung: Mizan, 1992

Ansari, Zafar Ishaq, \& Khurshid, Mawlana Sayyid Abul A'la Mawdudi: An Introduction to His Vision of Islam and Islamic Revival, dalam Khurshid Ahmad \& Zafar Ishaq Ansari (Ed.), "Islamic Perspectives: Studies in Honour of Mawlana Sayyid Abul A'la Mawdudi," Leicester: Islamic Foundation, 1980

Burhani MS-Hasbi Lawrens, Kamus Ilmiah Populer, Jombang: Lintas Media, t.t.

Esposito, Islam and Politics, Syracuse: Syracuse University Press), 1987

Ghazali, Muhammad, al-,Kayfa Nata'amal ma'al-Qur'an, Mesir: al-Ma'had al-Alami li al-Fikr al-Islami, 1991

Hakim, Abdul Hamid, al-Bayan, Padang Panjang: Pustaka Sa'diyah, t.t.

Hasan, Ahmad, Early Development of Islamic Jurisprudence, Islamabad: Islamic Research Institute, 1970

Ibn Ahmad al-Makki, Muwaffaq, al-, Manaqib al-Imam al-A'zham Abu Hanifah, Haidarabad, India: Dairatul Ma'arif, 1321 $\mathrm{H}$

Ibn Subki, Taj al-Din , Abdul Wahhab, Jam' al-Jawami', Mesir: Dar al-Fikr, 1982

Iqbal, Muhammad, Rekonstruksi Pemikiran Islam: Studi tentang Kontribusi Gagasan Iqbal dalam Pembaharuan Hukum Islam, Medan: Kalam Mulia, 1993

Iqbal, Muhammad, The Reconstruction of Religious Thought in Islam, Lahore: Institute of Islamic Culture, t.t.

113 Al-Fikra: Jurnal Ilmiah Keislaman, Vol.3, No.1, Januari-Juni 2004 
Mahendra, Yusril Ihza, Modernisme dan Fundamentalisme dalam Politik Islam, Jakarta: Paramadina, 1999

Maududi, Abu al-A'la, al-, The Islamic Law and Constitution, Terj. Asep Hikmat, Hukum dan Konstitusi Sistem Politik Islam Abl A'la al-Maududi, Bandung: Mizan, 1994 , al-Khilafah wa al-Mulk, Kuwait: Dar al-Qalam, 1978 , The Islamic Law and Constitution, Lahore: Islamic Publication Ltd., 1975

Praja, Juhahay S., Filsafat Hukum Islam, Bandung: Pusat Penerbitan Universitas LPPM Universitas Islam Bandung, 1995

Qardhawy, Yusuf, al-, Al-Ijtihad al-Mu'ashir baina al-Indilbaath wa al-Infiraath, Mesir: Dar al-Tauzi' wan Nasyr alIslamiyah, 1994

Rahman, "The Qur'anic Concept of God, the Universe and Man", terjemahan T.A. Amal, Metode dan Alternatif Neo Modernisme Islam, Bandung: Mizan, 1987

Rahman, Fazlu, Islam, Chicago: University of Chicago Press, 1979

Rahman, Major Temes of The Qur'an, terj. Anas Mahyuddin, Bandung: Pustaka, 1983

Syaltut, Mahmud, al-Islam: 'Aqidah wa Syari'ah, Kairo: Dar al-Kitab al-'Arabi, 1372

1Juhaya S. Praja, Filsafat Hukum Islam, (Bandung: Pusat Penerbitan Universitas LPPM Universitas Islam Bandung, 1995), hlm. 10.

'Mahmud Syaltut, al-Islam: 'Aqidah wa Syari'ah, (Kairo: Dar al-Kitab al'Arabi, 1372), hlm. 5.

${ }^{3} \mathrm{Abu}$ al-A'la al-Maududi, The Islamic Law and Constitution, Terj. Asep Hikmat, Hukum dan Konstitusi Sistem Politik Islam Abl A'la al-Maududi, (Bandung: Mizan, 1994), hlm. 72.

114 Al-Fikra: Jurnal Ilmiah Keislaman, Vol.3, No.1, Januari-Juni 2004 
${ }^{4}$ Al-Maududi, The Islamic Law and Constitution, (Pakistan: Islamic Publications Ltd., t.t.), hlm. 53

${ }^{5}$ Ahmad Hasan, Early Development of Islamic Jurisprudence, (Islamabad: Islamic Research Institute, 1970), hlm. 40.

6Fazlu Rahman, Islam, (Chicago: University of Chicago Press, 1979), hlm. 79, 111.

7Ibid., hlm. 196-206; Esposito, Islam and Politics, (Syracuse: Syracuse University Press), 1987), hlm. 33-36.

8Ishtiaq menggunakan kata absolutis untuk ulama tradisional dan individu pendukung syari'at yang ekstrim.

${ }^{9}$ Ishtiaq Ahmed, The Consept of an Islamic State: An Analysis of the Ideological Controversy in Pakistan, (New York: St. Martin's Press, 1987), hlm. 4.

${ }^{10}$ Ibid., hlm. 17.

${ }^{11}$ Al-Maududi, op. cit., hlm. 76.

${ }^{12}$ Ibid., hlm. 76-77.

${ }^{13}$ Khurshid \& Zafar Ishaq Ansari, Mawlana Sayyid Abul A'la Mawdudi: An Introduction to His Vision of Islam and Islamic Revival, dalam Khurshid Ahmad \& Zafar Ishaq Ansari (Ed.), "Islamic Perspectives: Studies in Honour of Mawlana Sayyid Abul A'la Mawdudi," (Leicester: Islamic Foundation, 1980), hlm. 363

${ }^{14} \mathrm{Abul}$ A'la al-Maududi, The Islamic Law and Constitution, (Lahore: Islamic Publication Ltd., 1975), hlm. 123

15Ibid., hlm. 125

${ }^{16}$ Iqbal lahir pada tahun 1877, sedangkan Maududi lahir pada tahun 1903. Ini berarti antara Iqbal dan Maududi terpaut beda usia sekitar 26 tahun. Muhammad Iqbal, Rekonstruksi Pemikiran Islam: Studi tentang Kontribusi Gagasan Iqbal dalam Pembaharuan Hukum Islam, (Medan: Kalam Mulia, 1993), hlm. 1

${ }^{17}$ Muhammad Iqbal, Rekonstruksi Pemikiran..., op.cit., hlm. 53

${ }^{18} \mathrm{Abul}$ A'la al-Maududi, The Islamic Law and Constitution, (Lahore: Islamic Publication Ltd., 1975), hlm. 125

${ }^{19}$ Mukti Ali, Mukti Ali, Mukti Ali, Alam Pikiran Islam Modern Di India dan Pakistan, (Bandung: Mizan, 1992), hlm. 242.

${ }^{20} \mathrm{Ibid}$. 1978), hlm. 74

${ }^{21}$ Abul A'la al-Maududi, al-Khilafah wa al-Mulk, (Kuwait: Dar al-Qalam,

${ }^{22}$ Ayat yang berhubungan dengan ini adalah Q.S. al-Nahl: 36; Q.S. alBayyinah: 5; Q.S. al-A'raf: 3; Q.S. al-Ra'd: 37; Q.S. al-Jasiyah: 18; Q.S. al-Baqarah: 229; Q.S. al-Talaq: 1; Q.S. al-Maidah: 44-47, 50; dan Q.S. al-Nisa: 60

${ }^{23}$ Abul A'la al-Maududi, The Islamic Law..., op.cit., hlm. 123

115 Al-Fikra: Jurnal Ilmiah Keislaman, Vol.3, No.1, Januari-Juni 2004 
${ }^{24}$ Ibid.

${ }^{25}$ Ibid.

${ }^{26}$ Ibid., hlm. 124.

${ }^{27}$ Ibid.

${ }^{28}$ Yusril Ihza Mahendra, Modernisme dan Fundamentalisme dalam Politik Islam, (Jakarta: Paramadina, 1999), hlm. 225

${ }^{29}$ Abul A'la al-Maududi, The Islamic Law..., op.cit., hlm. 123-124

${ }^{30}$ Maududi dalam memformulasikan konsep hukumnya, ia selalu melandasinya dengan prinsip Islam, yang salah satunya adalah tauhid (keesaan Tuhan, the unity of Godhead). Abul A'la al-Maududi, al-Khilafah wa..., op.cit., hlm. 13

${ }^{31}$ Yusril Ihza Mahendra, op.cit., hlm. 223

${ }^{32}$ Ibid.

${ }^{33}$ Abul A'la al-Maududi, The Islamic Law..., op. cit., hlm. 128

${ }^{34}$ Ibid., hlm. 129

${ }^{35}$ Muhammad Iqbal, The Reconstruction of Religious Thought in Islam, (Lahore: Institute of Islamic Culture, t.t), hlm. 168

${ }^{36}$ Abul a'la al-Maududi, op.cit., hlm. 96-97

${ }^{37}$ Abdul Hamid Hakim, al-Bayan, Padang Panjang: Pustaka Sa'diyah, t.t.), Jilid. II, hlm. 194

${ }^{38}$ Taj al-Din 'Abdul Wahhab Ibn Subki, Jam' al-Jawami', Juz II, (Mesir: Dar al-Fikr, 1982), hlm. 379

${ }^{39}$ Muhammad Iqbal, Rekonstruksi Pemikiran..., op.cit., hlm. 148

40Ibid., hlm. 86

${ }^{41}$ Abul A'la al-Maududi, op.cit., hlm. 97-98

${ }^{42}$ Muhammad Rasyid Ridha, Tafsir al-Manar, Juz V, Cet. III, hlm. 205

43Yusuf al-Qardhawy, Al-Ijtihad al-Mu'ashir baina al-Indilbaath wa alInfiraath, (Mesir: Dar al-Tauzi' wan Nasyr al-Islamiyah, 1994), hlm. 16

${ }^{44}$ Ibid.

45Ibid., hlm. 23

46Muhammad Iqbal, Rekonstruksi..., op.cit., hlm. 86

${ }^{47}$ Muhammad Iqbal, The Recontruction of..., op.cit., hlm. 174

${ }^{48} \mathrm{Ibid}$.

${ }^{49}$ Yusuf al-Qardhawy, op. cit., hlm. 128-141

${ }^{50}$ Abul A'la al-Maududi, al-Khilafah wa... , op.cit., hlm. 310

${ }^{51}$ Muwaffaq ibn Ahmad al-Makki, Manaqib al-Imam al-A'zham Abu Hanifah, (Haidarabad, India: Dairatul Ma'arif, 1321 H), Jilid 2, hlm. 133. Maududi dalam merumuskan pemikirannya tentang kodifikasi hukum, ia juga banyak mengutip pemikiran Abu Hanifah, termasuk kajian terhadap lembaga-

116 Al-Fikra: Jurnal Ilmiah Keislaman, Vol.3, No.1, Januari-Juni 2004 
lembaga hukum serta pembagian-pembagiannya. Abul A'la al-Maududi, AlKhilafah wa..., op. cit., hlm. 303-312

${ }^{52}$ Ibid., hlm. 38

${ }^{53}$ Abul A'la al-Maududi, The Islamic Law..., op.cit., hlm. 130

${ }^{54}$ Muhammad al-Ghazali, Kayfa Nata'amal ma'al-Qur'an, (Mesir: alMa'had al-Alami li al-Fikr al-Islami, 1991), hlm. 240

${ }^{55}$ Ibid.

${ }^{56}$ Abul A'la al-Maududi, The Islamic Law..., op.cit., hlm. 131

57Ibid., hlm. 132

${ }^{58}$ Ibid., hlm. 133

${ }^{59}$ Fazlur Rahman, "The Qur'anic Concept of God, the Universe and

Man", terjemahan T.A. Amal, Metode dan Alternatif Neo Modernisme Islam, (Bandung: Mizan, 1987), hlm. 75

${ }^{60}$ Fazlur Rahman, Major Temes of The Qur'an, terj. Anas Mahyuddin,

(Bandung: Pustaka, 1983), hlm. 55

${ }^{61}$ Abul A'la al-Maududi, The Islamic Law..., op.cit., hlm. 108

62Ibid., hlm. 112

63Ibid., hlm. 109

${ }^{64}$ Ibid. hlm. 112

${ }^{65}$ Ibid., hlm. 113

${ }^{66} \mathrm{Ibid}$.

${ }^{67}$ Ibid.

${ }^{68}$ Abul A'la al-Maududi, The Islamic Law..., op.cit., hlm. 248

117 Al-Fikra: Jurnal Ilmiah Keislaman, Vol.3, No.1, Januari-Juni 2004 